Albada, A., Ausems, M.G.E.M., Dulmen, S. van. Counselee participation in follow-up breast cancer genetic counselling visits and associations with achievement of the preferred role, cognitive outcomes, risk perception alignment and perceived personal control. Social Scie

\& Medicine: 2014, 116(sept), 178-186

\begin{tabular}{|l|l|}
$\begin{array}{l}\text { Postprint } \\
\text { Version }\end{array}$ & 1.0 \\
\hline Journal website & http://www.sciencedirect.com/science/article/pii/S0277953614004419 \\
\hline Pubmed link & $\underline{\text { http://www.ncbi.nlm.nih.gov/pubmed/25016325 }}$ \\
\hline DOI & $10.1016 /$ j.socscimed.2014.07.012 \\
\hline
\end{tabular}

This is a NIVEL certified Post Print, more info at http://www.nivel.eu

\title{
Counselee participation in follow-up breast cancer genetic counselling visits and associations with achievement of the preferred role, cognitive outcomes, risk perception alignment and perceived personal control
}

\author{
AKKe AlbadA ${ }^{A, B,}$, MARGREet G.E.M. AuSEMS ${ }^{A}$, SANDRA VAN DULMEN ${ }^{\mathrm{B}, \mathrm{C}, \mathrm{D}}$
}

${ }^{a}$ Department of Medical Genetics, University Medical Centre Utrecht, Postbus 85500, 3508 AB Utrecht, The Netherlands

${ }^{\mathrm{b}}$ NIVEL (Netherlands Institute for Health Services Research), Utrecht, The Netherlands

${ }^{\mathrm{c}}$ Department of Primary and Community Care, Radboud University Medical Centre, Nijmegen, The Netherlands

${ }^{d}$ Department of Health Sciences, Buskerud University College, Drammen, Norway

\begin{abstract}
The purpose of the study was to assess the counselee participation in the followup visits, compared to the first visits, for breast cancer genetic counselling and to explore associations with counselees' achievement of their preferred role in decision making, information recall, knowledge, risk perception alignment and perceived personal control.

First and follow-up visits for breast cancer genetic counselling of 96 counselees of a Dutch genetics center were videotaped (2008-2010). Counselees completed questionnaires before counselling (T1), after the follow-up visit (T2) and one year after the follow-up visit (T3). Consultations were rated with the Roter Interaction Analysis System (RIAS). Counselee participation was measured as the percentage of counselee utterances, the percentage of counselee questions and the interactivity (number of turns per minute).

Follow-up visits had higher levels of counselee participation than first visits as assessed by the percentage of counselee talk, the interactivity and counselee questions. More counselee talk in the follow-up visit was related to higher achievement of the preferred role (T2) and higher perceived personal control (T3). Higher interactivity in the follow-up visit was related to lower achievement of the preferred role in decision making and lower information recall (T2). There were no significant associations with the percentage of
\end{abstract}


Albada, A., Ausems, M.G.E.M., Dulmen, S. van. Counselee participation in follow-up breast cancer genetic counselling visits and associations with achievement of the preferred role, cognitive outcomes, risk perception alignment and perceived personal control. Social Science \& Medicine: 2014, 116(sept), 178-186

questions asked and none of the participation measures was related to knowledge, risk perception alignment and perceived personal control (T2).

In line with the interviewing admonishment 'talk less and listen more', the only assessment of counselee participation associated to better outcomes is the percentage of counselee talk. High interactivity might be associated with lower recall in breast cancer genetic counselees who are generally highly educated. However, this study was limited by a small sample size and a heterogeneous group of counselees. Research is needed on the interactions causing interactivity and its relationships with involvement in decision making and recall.

\section{INTRODUCTION}

Cancer genetic counselling aims to help counselees to make their own choices with regard to DNA-testing, periodic surveillance and informing relatives about their risks and to regain a sense of control (Resta et al., 2006). Several outcomes have been identified. Achievement of the preferred role in decision making is important for counselees to make their own decision (Wang et al., 2004). Counselees' information recall, knowledge of hereditary breast cancer and risk perception alignment are relevant to evaluate whether the counsellor's information was remembered, understood and whether it altered the counselee's feelings about her risk (Kasparian et al., 2007). Finally, the level of perceived personal control is assessed as an aim. While counselling has been shown to modestly improve breast cancer genetics knowledge (Meiser et al., 2001), it has little positive impact on counselees' risk perception alignment (Smerecnik et al., 2009 and Butow et al., 2003) and provides small increases in the sense of personal control (Pieterse et al., 2011). Therefore, new ways for improving the counselling process should be found.

Breast cancer genetic counselling usually consists of pre-test and post-test counselling, each dealt with in mostly one visit (Hopwood et al., 2003). The first visit focuses on the interpretation of personal and family cancer histories and education about hereditary breast cancer and DNA-testing. In the Netherlands, approximately two-third of the counselees receives an indication for DNA-testing for herself or an affected relative (Albada et al., 2012). Several months later, these counselees attend a follow-up visit. In this visit the counselee receives risk estimates and surveillance recommendations for herself and first degree relatives. Therefore, the follow-up visit is a crucial moment for achieving improved outcomes. However, most process studies have been restricted to the first visit and little is known about the follow-up visit for breast cancer genetic counselling (Meiser et al., 2008).

Based on evidence from neuropsychological studies, increased counselee participation might hold the key to improving outcomes. These studies indicate that to better retain information, it needs to be processed elaborately in the brain, i.e. one has to attach meaning to it (Sousa, 2006). More active participation, i.e. talking instead of only listening, activates more senses, increases elaborate processing and thereby enhances learning (Goswami, 2008). Better recall could thus be obtained by letting counselees discuss what the information means to them. Additionally, a consultation with higher interactivity contains shorter blocks of information which better fit the concentration span to be more easily processed and remembered (Sousa, 2006). Finally, counselee questions enable the counsellor to adjust information to the individual counselee, leading to more tailored and personalized information (Kelly et 
Albada, A., Ausems, M.G.E.M., Dulmen, S. van. Counselee participation in follow-up breast cancer genetic counselling visits and associations with achievement of the preferred role, cognitive outcomes, risk perception alignment and perceived personal control. Social Science 7 \& Medicine: 2014, 116(sept), 178-186

al., 2005 and Van Dijk et al., 2005). People process personally tailored information more elaborately and it is therefore better remembered (Sousa, 2006). Literature thus indicates that more counselee participation could be related to improved knowledge and recall. In cancer care, patient question asking was also found to be related to increased recall of information, presumably because the questions enabled more tailored information giving by the health care provider (Van der Meulen et al., 2008). Additionally, higher levels of interactivity could create more opportunity for the counselee to express perceptions about risk and values concerning screening, necessary for involvement in decision making (Street et al., 2009). The counselee asking questions, sharing his/her view and providing information are important conditions for patient-centred communication, which is postulated to increase counselee's knowledge, shared understanding, the quality of decisions and selfmanagement (Street et al., 2009).

Indeed, studies with simulated counselees indicate positive effects of counselee participation in the first visits, as more counselee talk was found to be associated with higher satisfaction (Meiser et al., 2008). Also, higher interactivity enabled low literate simulated counselees to learn and there was increased learning in consultations with more personalised information (Roter et al., 2009). However, previous studies focused on first visits for breast cancer genetic counselling, which are known for their low levels of counselee participation, as assessed by their percentage of talk, the interactivity and the number of counselee questions (Butow and Lobb, 2004, Ellington et al., 2005, Ellington et al., 2006, Lobb et al., 2001, Roter et al., 2009, Lobb et al., 2002, Lobb et al., 2004, Lobb et al., 2005, Meiser et al., 2008, Pieterse et al., 2005a and Pieterse et al., 2007). Also, findings with simulated counselees may not hold true in real consultations.

The current paper is the first to explore associations of counselee participation in the follow-up breast cancer genetic counselling consultation to counselee-reported outcomes. We will assess (1) the counselee participation in the follow-up consultation and compare this to the counselee participation in the first consultation, (2) the associations between counselee participation in the follow-up visit and counselees' achievement of their preferred role in decision making, information recall and knowledge, risk perception alignment and perceived personal control after the follow-up visit and one year after the (final) follow-up visit.

\section{METHODS}

The present study was conducted as part of a larger study on breast cancer genetic counselling at the department of Medical Genetics of the University Medical Centre (UMC) Utrecht (Albada et al., 2012). The study was approved by the medical ethical committee of this hospital. Consecutive new counselees were included from February 2008 to April 2010. Counselees who were aged 18 years or older and were the first of their first degree family to seek breast cancer genetic counselling, were sent information about the study and an opt-out form including a question about reasons of withdrawal. Counselees were ineligible if they lacked internet or email access. At the start of the first consultation the counsellor collected the informed consent form. All 13 counsellors performing follow-up breast cancer genetic counselling consultations at the department participated and counselled 2 to 17 counselees each. Counsellors were clinical geneticists $(n=3)$, clinical geneticists in training $(n=4)$, genetic counsellors $(n=3)$ or genetic counsellors in training $(n=3)$. 
Albada, A., Ausems, M.G.E.M., Dulmen, S. van. Counselee participation in follow-up breast cancer genetic counselling visits and associations with achievement of the preferred role, cognitive outcomes, risk perception alignment and perceived personal control. Social Science \& Medicine: 2014, 116(sept), 178-186

Both first and follow-up consultations were videotaped and the camera was directed at the counsellor. 96 counselees had a follow-up consultation that was videotaped ( Fig. 1). Nine counselees had a follow-up consultation that was not videotaped due to logistic failure. Of two counselees there was no videotape of the first consultation due to technical problems. One first consultation was only videotaped for the first half and one recording missed the first part of the consultation.

\section{[FIGURE 1]}

Six counselees had an intermediate follow-up consultation between the initial and the final follow-up consultation. Mostly this intermediate consultation was to clarify the family medical history. These intermediate consultations were not taken into account in this study. Counselees completed a digital questionnaire before counselling (T1), approximately one week after the final follow-up visit (T2) and approximately one year after the final follow-up visit (T3). Counselees received a summary letter approximately one month after the final visit. Data were initially gathered for a randomized controlled trial of the effects of a pre-visit tailored website on genetic counselling outcomes for hereditary breast cancer in which participants were randomized to receive usual care or usual care plus an educational website. In the current study, this group allocation is controlled for.

\subsection{Counselee characteristics}

Age, having children, family cancer history and educational attainments were assessed in the baseline counselee questionnaire. All but the latter two were derived from the medical file if missing. Two missing values on education were imputed with the median. Counsellors estimated the risk for the counselee to develop breast cancer (again) with Claus tables and the Claus extended formula as integrated in the Dutch guidelines (Van Asperen et al., 2004). They completed this risk on a 0-100\% visual analogue scale (VAS) in a questionnaire after the final visit. The risk was checked with the medical files and when revised due to e.g. changes in the family cancer history, we copied the risk from the medical file. For five affected counselees with an uninformative DNA-test result their risk was missing and was imputed with the mean risk for affected counselees who received an indication for testing and an uninformative test result. Breast cancer disease status, indication for DNA-testing and test results were derived from the medical file.

\subsection{Questionnaires}

The T1 questionnaire assessed the preferred level of involvement in decision-making and evaluated this role with items adapted for breast cancer genetic counselling from Gattellari et al., 2001 and Sutherland et al., 1989). The preference for involvement in decision making around DNA testing, adhering to surveillance recommendations and informing relatives about risks and surveillance, was assessed at T1 and T2. For the analyses we used the T2 assessment because the consultation itself can change the preference (Butow et al., 1997). Counselees were asked to select a response to a question assessing preferences: (1) the counsellor makes all decisions using all that he/she knows about genetic counselling; (2) the counsellor makes all decisions but strongly considers my opinion; (3) the counsellor and I make all decisions together; (4) I make all decisions but strongly consider the counsellor's opinion; 5) I make all decisions using all that I know and learn about genetic counselling. Counselees 
Albada, A., Ausems, M.G.E.M., Dulmen, S. van. Counselee participation in follow-up breast cancer genetic counselling visits and associations with achievement of the preferred role, cognitive outcomes, risk perception alignment and perceived personal control. Social Science \& Medicine: 2014, 116(sept), 178-186

evaluated their level of involvement in decision making by selecting one of the responses formulated in the past tense. Counselees were considered to have achieved their preferred level of involvement if they had given the same score to the preference and the evaluation.

Questionnaires included seven items to assess the level of accurate knowledge about hereditary breast cancer ( Pieterse et al., 2005b). Respondents indicated whether each item was correct, incorrect, or whether they did not know. The knowledge score was the number of correct answers.

Counselees rated their perceived risk that they themselves would (re-)develop breast cancer in the future on a VAS (0-100\%). Risk perception was defined as aligned if the counselee and counsellor estimates were within the same risk category, either population or slightly increased $(<20 \%)$, moderate $(20-30 \%)$ or high risk $(\geq 30 \%)$ of developing breast cancer (again) ( CBO, 2008). The surveillance recommendations are based on these risk categories ( Van Dijk et al., 2004). The T4 questionnaire additionally assessed whether the counselee had risk reducing breast surgery. The feeling of being in control (cognitive, behavioural and decisional) as related to the possibility of carrying hereditary breast cancer was assessed using the validated Dutch Perceived Personal Control questionnaire (Smets et al., 2006 and Pieterse et al., 2007). The score (mean of all 9 items) ranges from 0 to 2.

\subsection{Information recall}

Counselees' recall of information from the visit was assessed at T2 with seven multiple choice indications of whether a topic was discussed, e.g. limitations of DNA-testing and involving family members, with responses 1) no, not discussed, 2) yes it was discussed but I don't remember what was said, 3) yes, namely, with an invitation to write down what the counselee recalled (Jansen et al., 2008). Coders assessed whether the topic was discussed in the visit based on the videotape. Subsequently, items described were compared with the items mentioned by the counsellor (Jansen et al., 2008). If all items regarding a topic discussed were (correctly) described two points were given, if a part of the items was correctly described one point was given and if no items were correctly described no points were given. The percentage of accurate recall was calculated by dividing the sum of these points for all seven topics by the highest possible score based on the number of discussed topics. A second coder coded a random 10\%. Interrater reliability (intra class correlation) was .94.

\subsection{Coding of videotapes}

Verbal communication was analysed with the Roter's Interaction Analysis System (RIAS) (Roter, 2006), adjusted for genetic counselling (Pieterse et al., 2005a). In the RIAS verbal dialogue is analyzed utterance by utterance, in mutually exclusive categories. An utterance is the smallest discriminable speech segment which expresses or implies a complete thought (Roter and Larson, 2002). We coded directly from the videotapes with the software program Observer XT7, allowing for analysis of the number and sequence of utterances (Noldus et al., 2000).

For the first consultation, we calculated the participation measures for the whole consultation and for the last part of the consultation, i.e. the whole consultation minus the first phase (until the family history was completed). The first phase of the first consultation mainly consist of assessing the personal and family cancer history (Butow and Lobb, 2004 and Pieterse et al., 2006). The remaining part mainly aims to 
Albada, A., Ausems, M.G.E.M., Dulmen, S. van. Counselee participation in follow-up breast cancer genetic counselling visits and associations with achievement of the preferred role, cognitive outcomes, risk perception alignment and perceived personal control. Social Science 7 \& Medicine: 2014, 116(sept), 178-186

educate and counsel counselees (Resta et al., 2006) and might be more comparable to follow-up visits.

RIAS coding was conducted by five trained coders of whom two only coded first consultations and two others only coded final consultations. Reliability coefficients for categories with mean occurrence $>2 \%$ were calculated (Roter, 2006). Interrater reliability was calculated between the three coders of the first consultations and between the three coders of the follow-up consultations on a random $7 \%$ of the consultations. The main coders of the first and follow-up visits recoded a random $10 \%$ of their consultations. The inter-coder reliability (intra class correlation, ICC) for the first visits averaged .92 (range .78-1) and intra-coder reliability averaged .88 (.58-.99). For the follow-up consultations inter-coder reliability coefficients averaged .86 (.39-.99). Intra-coder reliability coefficients averaged .96 (.75-1). The lowest values of the inter-coder reliability in the follow-up visits (.39 and .51) concerned the RIAS category agreement (implying agreement or acceptance, e.g. yes, indeed) for counsellors and counselees respectively. This category was hard to distinguish from the RIAS category backchannel responses (implying attentiveness, e.g. hmmm, yeah). We therefore lumped agreements and backchannels.

\section{PARTicipation MEASURES}

The percentage of counselee utterances and the number or percentage of questions are frequently used to assess counselee participation (Pieterse et al., 2005a, Epstein and Street, 2007 and Ellington et al., 2007). We calculated the counselee talk (utterances) and questions as a percentage of the total number of utterances in the consultation. Interactivity has been introduced as a new measure in simulated consultations (Roter et al., 2008 and Roter et al., 2007), but has not yet been assessed in routine consultations. The interactivity is the mean number of turns per minute between the counsellor (s) and the counselee (s). All shifts of floor are counted as a turn except for agreements and backchannels (Roter et al., 2008).

If two counsellors were present, their utterances were added. Similarly, if companions were present their utterances were added to those of the counselee (Pieterse et al., 2007). With regard to recall it has been found that the percentage of recall was not higher if a companion had been present during the consultation (Jansen et al., 2010).

\section{ANALYSIS}

We compared the participation measures of the follow-up consultations with the first consultations with paired $t$-tests (two-sided significance testing). Additionally, we checked whether higher counselee participation in the follow-up consultation was associated with outcomes using multilevel regression analyses. A multilevel model was chosen because counselees were nested within counsellors. As the follow-up consultation was mostly (90 of 96) performed by the same counsellor as the first consultation the counselees were grouped based on the counsellor of their first consultation. The intra class correlation of the null model varied between 0 and $4.4 \%$ for the various outcomes. We applied multilevel analyses with random intercept at the counsellor level. Multilevel logistic regression analyses were performed for risk perception and achievement of the preferred level of involvement (xtlogit). For the other outcomes we used multilevel linear regression with maximum likelihood estimation (xtmixed, mle). We controlled for counselee age, education, disease 
Albada, A., Ausems, M.G.E.M., Dulmen, S. van. Counselee participation in follow-up breast cancer genetic counselling visits and associations with achievement of the preferred role, cognitive outcomes, risk perception alignment and perceived personal control. Social Science \& Medicine: 2014, 116(sept), 178-186

status, breast cancer risk and group allocation. For all analyses except for recall, we additionally controlled for baseline values. The AIC (Akaike Information Criterion) was used to assess the model fit for the basic model (model 1) and the model including the control variables (model 2). Analysed were conducted using Stata 12.

\section{RESULTS}

\subsection{Counselee characteristics}

The mean age was 44.1 and $40 \%$ of the counselees was highly educated (Table 1 ). For 69 counselees a DNA-test was performed for themselves or for an affected relative. For breast cancer affected counselees there was more often a DNA-test performed than for unaffected counselees who mostly had to request their relative to perform the DNA-test $(\mathrm{Chi}=13.05 ; P=.000)$. If the relative did not agree with the DNA test, or has deceased, no DNA-test was performed. In such a case the risk estimate and surveillance recommendations were based on the medical family history as discussed in the follow-up consultation. Post-counselling the preference for involvement in decision making was significantly higher compared to precounselling $\left(\mathrm{Chi}^{2}=9.68 ; P=.046\right)$. Four counselees had risk reducing breast surgery at T4. Two of these counselees underestimated their risk, however, this may be due to their lowered risk after the risk reducing breast surgery.

\section{[TABLE 1]}

\subsection{Breast cancer genetic counselling outcomes}

Counselees correctly recalled less than half of the information items discussed in the follow-up visit (Table 2). Almost three quarters of the counselees (72\%) achieved their preferred role in decision making. Scores for knowledge and perceived personal control were significantly higher post-counselling and one year post-counselling, compared to pre-counselling. The percentage of counselees who had an accurate risk perception was significantly higher at post-counselling compared to pre-counselling, but not at one year post-counselling compared to pre-counselling.

[TABLE 2]

\subsection{Counselee participation in the follow-up compared to the first visits}

Counselees participated significantly more in the follow-up compared to the first visits as measured by the percentage of counselee utterances, the interactivity and the percentage of counselee questions $(N=94$; Table 3$)$. No significant differences in the participation measures were found between breast cancer affected and breast cancer unaffected counselees.

\section{[TABLE 3]}

\subsection{Associations between counselee participation and outcomes of the follow-up visit}

The percentage of counselee utterances in the follow-up consultation was positively related to counselees' achievement of their preferred role in decision making $(\beta=.60$, $p=.048$; Table 4). The interactivity, i.e. number of turns per minute, was negatively related to the achievement of the preferred role in decision making $(\beta=-.79 ; p=$ $.01)$ and to the percentage of information recalled $(\beta=-.29 ; p=.01)$. The percentage 
Albada, A., Ausems, M.G.E.M., Dulmen, S. van. Counselee participation in follow-up breast cancer genetic counselling visits and associations with achievement of the preferred role, cognitive outcomes, risk perception alignment and perceived personal control. Social Science \& Medicine: 2014, 116(sept), 178-186

of counselee utterances was positively related to perceived personal control one year after the follow-up visit $(\beta=.19 ; p=.04)$, while there was no significant association with information recall. The percentage of counselee questions was not significantly associated with any of the outcomes.

\section{[TABLE 4]}

\subsection{Sensitivity analyses}

Several sensitivity analyses were performed. First, we performed the multilevel regression analyses with the counselees grouped per counsellor of the follow-up visit instead of the first visit and changes in results did not cross significance thresholds. Second, we performed the multilevel regression analyses with the control variable of education replaced by whether a DNA-test was performed or not. Third, we performed these analyses with education replaced by whether there was an uninformative test result or not. For both the second and third type of sensitivity analyses the association between the percentage of counselee utterances and achievement of the preferred involvement in decision making was not significant any more. Other results did not change. Fourth, we conducted the analyses without the six counselees who had seen a different counsellor at their follow-up compared to their first visit. The association between interactivity, achievement of preferred role and recall remained significant. The association between the percentage of counselee utterances with perceived personal control one year after counselling was $B=.19$ ( $P$ $=.051)$ and with achievement of the preferred role was $B=.62(P=.05)$. However, withouth these six counselees power was further limited with 9 independent variables and 78 respondents and we therefore chose to report the analyses with these six counselees included.

\section{DISCUSSION}

This paper firstly aimed to compare the counselee participation in the follow-up breast cancer genetic counselling visits with the first visits. These first visits have been described as educational with little counselee participation. The current study shows that this characterisation does not hold true to the same extent for the followup visits as these contain significantly higher percentages of counselee talk, higher interactivity, and higher percentages of counselee questions than the first visits. Interestingly, a study of genetic counselling for pre-symptomatic testing in the USA showed a low percentage of counselee talk in both the follow-up and first consultations (Ellington et al., 2007). However, in that study counselling about emotional consequences and informing relatives was given after the follow-up visit and this might distort the comparison. Our study shows that with counselees who are the first in their family to request counselling, follow-up visits involve counselees more than the first visits.

Furthermore, this paper explored associations of counselee participation with genetic counselling outcomes. A higher percentage of counselee talk was associated with more achievement of the preferred role in decision making. Generally, counselees preferred more involvement in decision making than experienced. Apparently, when counselees talk more, they perceive more involvement in decision making, or vice versa, when they feel more involved in decision making they talk more. As their preferences for involvement were higher post-counselling than pre-counselling, 
Albada, A., Ausems, M.G.E.M., Dulmen, S. van. Counselee participation in follow-up breast cancer genetic counselling visits and associations with achievement of the preferred role, cognitive outcomes, risk perception alignment and perceived personal control. Social Science 7 \& Medicine: 2014, 116(sept), 178-186

counselees may need explicit invitations for involvement in decision making. The percentage of counselee talk was not significantly associated to recall and knowledge. In the follow-up visit the personal risk estimation and surveillance recommendations are conveyed and this information is highly personally relevant. Therefore, information in the follow-up visit might be processed elaborately regardless of the percentage of counselee talk. Furthermore, counselee participation was unrelated to risk perception alignment. The counselees' risk perception was more in line with the risk estimate post-counselling compared to pre-counselling, but many counselees still overestimated their risk. Due to the anchoring-and-adjust bias (counselees may adjust their perceived risk toward- but not equal to- the risk estimate provided) a completely correct perception may not be achievable (Linnenbringer et al., 2010). Given the lower risk perception alignment at one year follow-up compared to post counselling, the risk perception might further drift away from the risk estimate over time. Studies with shorter (six months) follow-up periods did not find significant deterioration (Pieterse et al., 2011 and Van Dijk et al., 2005).

Consistent with our expectation, counselee talk was positively associated with perceived personal control one year after the visit. This did not seem to be related to higher scores for the perceived participation in decision making (post hoc analysis, $r$ $=.02$ ). Instead, it might be related to a heightened needs fulfillment after counselling due to the higher percentage of counselee talk, as was shown in a previous study ( Dijkstra et al., 2013). Possibly, talking more in the follow-up visit could enable counselees to think about decisions and to behave according to their preferences, in other words, to gain a higher level of perceived personal control. Alternatively, those experiencing more control one year post-counselling might have been more in control during the consultation due to personal characteristics not included in this study.

The association of interactivity with both the achievement of the preferred role in decision making and information recall was unexpectedly negative. Several explanations are possible. Firstly, this was the first study to assess interactivity in real consultations, as opposed to simulated consultations (Roter et al., 2007, Roter et al., 2008 and Roter et al., 2009). In real consultations interactivity might not only be caused by shorter blocks of information, paraphrases and checks for understanding, which usually indicate good alignment between conversational partners (Roter, 2006). Higher rates of interactivity might also be due to lack of structure of the counsellor's information, repeated interruptions by counselees as a previous question was still unanswered and by poor listening of counsellors, which usually indicate a lack of alignment (Roter, 2006). This is to be assessed by future studies. Furthermore, a post hoc analysis showed that high rates of interactivity were associated to higher percentages of social talk (small talk) $(r=.49 ; P=.00)$. Whereas social talk is important to make the counselee feel at ease, it is unclear how these utterances are relevant for feelings of being involved in decision making. Future research should therefore focus on the type of interactions causing high interactivity and the associations of each of these with visit outcomes.

Secondly, counselees may gain from interactivity up to a certain level. A study with simulated first visits in the USA showed a low mean interactivity rate (2.3) (Roter et al., 2007) compared to 'real-life' first visits (5.6) in the current study. Unfortunately, we could not test whether there was a reverse U-curve relation as the lowest interactivity in this study was relatively high (2.97). 
Albada, A., Ausems, M.G.E.M., Dulmen, S. van. Counselee participation in follow-up breast cancer genetic counselling visits and associations with achievement of the preferred role, cognitive outcomes, risk perception alignment and perceived personal control. Social Science \& Medicine: 2014, 116(sept), 178-186

Thirdly, our finding may be explained by the high educational level of the counselees. The study of Roter et al. (2009) found that more interactive first visits resulted in more learning of low literate simulated counselees and found a trend for less learning of high literate simulated counselees. The authors postulate that higher interactivity compromises organized and comprehensive organization of information, which may hamper learning for those high literate, used to process large amounts of information. The current study sample was highly educated with only $2 \%$ of counselees not having finished high school, i.e. below 8th grade of education. This high educational level is representative for Dutch counselees and comparable to educational levels reported in the UK (Metcalfe et al., 2007), USA (Ellington et al., 2005) and Australia (Butow et al., 2003). For these highly educated counseleeslow levels of interactivity might not be a problem as they are able to grasp dense information. Future studies should clarify whether the optimal rate of interactivity differs for high versus lower educated counselees.

The current study adds to the discussion about how to capture counselee participation. In line with the interviewing admonishment 'talk less and listen more', the measure of counselee participation related to better outcomes was the percentage of counselee talk. As previous studies have also found significant associations with the percentage of counselee talk (Dijkstra et al., 2013 and Epstein and Street, 2007) we think that it can be considered an important indicator for participation. However, it is unknown how much speaking time counselees need to present their concerns, discuss their views and participate in decision making. For instance, a study of Langewitz et al. (2002) found that 2 min of uninterrupted patient speaking time at the start of the consultation was enough for patients to present their problem and determine the agenda. Future research might thus focus on the timing of counselee talk.

Furthermore, Roter et al. (2008) introduced interactivity as a new measure of patient participation that might be related to patient centred communication and better outcomes. However, the current study with real consultations suggests that higher interactivity might be negatively associated with recall and achievement of their preferred role in decision making in a population of highly educated counselees in breast cancer genetic counselling. Future research should assess whether frequent turn taking helps counselees to feel heard and understood. Surprisingly, the percentage of counselee questions was not significantly related to any of the outcomes and this might challenge its relevance. Asking questions was not hypothesized to have a direct beneficial effect on outcomes, but rather through receiving more personally relevant information. However, some variation in the percentage of questions might be explained by responsiveness to the counsellor, i.e. asking more questions when little personally relevant information is given and asking few questions if a lot of personally relevant information is given. When counsellors are responsive to the counselee's needs, the counselee would not need to ask questions and a significant association is not to be found (Stiles, 1989). This would be in line with results of Pieterse et al. (2007) indicating a negative association between the number of questions and counselee satisfaction with first consultations. Associational studies are not sensitive for this responsiveness and qualitative studies are needed to better grasp the level rapport. 
Albada, A., Ausems, M.G.E.M., Dulmen, S. van. Counselee participation in follow-up breast cancer genetic counselling visits and associations with achievement of the preferred role, cognitive outcomes, risk perception alignment and perceived personal control. Social Science \& Medicine: 2014, 116(sept), 178-186

\section{METHODOLOGICAL REFLECTION}

There are several strengths and limitations to this study. First, we corrected for the nesting of counselees within counsellors with multilevel regression. Hereby, we overcame a drawback of some prior studies on communication and outcomes in genetic counselling (Meiser et al., 2008). However, the number of 13 counsellors limited the power. Therefore, counsellor characteristics, such as gender and age, could not be involved in the analyses. Second, when the data for the study was collected the waiting time for DNA-test results was three to six months and this has recently been reduced to two months. Future studies should show whether this shortened time between the first and follow-up consultation will bring about changes in counselees' well-being, such as perceived personal control. Third, for the analyses we used counselees' preference for involvement in decision making from the postvisit questionnaire because these were higher than the pre-counselling preferences. No measurement shortly ( $<4-6$ months) prior to the follow-up consultation was available and preferences are subject to change over time (Butow et al., 1997). Fourth, we choose to analyse communication with RIAS. While this instrument is very valuable for assessing the structure of a consultation, it does not provide indepth information about the content of the visit (Sandvik et al., 2002). Therefore, we could not determine whether questions were answered appropriately and whether information was understandable. Future qualitative studies are needed to address these questions. Fifth, due to the exclusion criteria of having internet or email access, 24 (5.6\%) of the counselees who were sent study information were excluded and this might have biased results. Finally, this study did not involve the surveillance adherence. Future long term research should evaluate the communication in genetic counselling with regard to adherence. However, counselees' involvement in decision making, i.e. making their own decision, is recently being recognized as an important outcome, regardless of adherence (Resta et al., 2006). Finally, while the heterogeneous group of counselees in this study reflects the practice of breast cancer genetic counselling, the heterogeneity and small sample size limit the statistical power. Preventive options and informing of relatives are different for counselees with or without an indication for DNA-testing and for those with an uninformative versus a BRCA1/2 test result. Nonetheless, it is important to report about the followup visits for breast cancer genetic counselling while including all these counselees.

\section{Practice implications}

The results of this study support the advice for genetic counsellors to 'talk less and listen more'. To feel more involved in decisions and regain a sense of personal control counselees could be explicitly invited to talk about their perceptions of their risk and their surveillance options (Van Dijk et al., 2004, Pieterse et al., 2006, Michie et al., 2003 and Vos et al., 2011).

\section{ACKNOWLEDGEMENTS}

We would like to thank all participating counselees, genetic counselors and clinical geneticists. Furthermore, we would like to thank the coders Bianca Wiering and Melissa Gültzou. This study was funded by a grant from the Dutch Cancer Society (Nivel 2010-4875). 
Albada, A., Ausems, M.G.E.M., Dulmen, S. van. Counselee participation in follow-up breast cancer genetic counselling visits and associations with achievement of the preferred role, cognitive outcomes, risk perception alignment and perceived personal control. Social Science \& Medicine: 2014, 116(sept), 178-186

\section{REFERENCES}

Albada et al., 2012 A. Albada, S. Van Dulmen, D. Lindhout, J.M. Bensing, M.G. Ausems A pre-visit tailored website enhances counselees' realistic expectations and knowledge and fulfils information needs for breast cancer genetic counselling Fam Cancer, 11 (1) (2012), pp. 85-95

Butow et al., 1997 P.N. Butow, M. Maclean, S.M. Dunn, M.H. Tattersall, M.J. Boyer The dynamics of change: cancer patients' preferences for information, involvement and support Ann. Oncol., 8 (1997), pp. 857-863

Butow et al., 2003 P.N. Butow, E.A. Lobb, B. Meiser, A. Barratt, K.M. Tucker Psychological outcomes and risk perception after genetic testing and counselling in breast cancer: a systematic review Med. J. Aust., 178 (2) (2003), pp. 77-81

Butow and Lobb, 2004 P. Butow, E. Lobb Analyzing the process and content of genetic counseling in familial breast cancer consultations J. Genet. Couns., 13 (5) (2004), pp. 403424

CBO, 2008 CBO (The Dutch Institute for Healtcare Improvement) Richtlijn Mammacarcinoom [Guideline for Breast Cancer] (2008) (2.0) www.oncoline.nl

Dijkstra et al., 2013 H. Dijkstra, A. Albada, C. Klöckner-Cronauer, M.G.E.M. Ausems, Van S. Dulmen Nonverbal communication and conversational contribution in breast cancer genetic counseling: are counselors' nonverbal communication and conversational contribution associated with counselees' satisfaction, needs fulfillment and state anxiety in breast cancer genetic counseling? Patient Educ. Couns., 93 (2) (2013), pp. 216-223

Ellington et al., 2005 L. Ellington, D. Roter, W.N. Dudley, B.J. Baty, R. Upchurch, S. Larson, J.E. Wylie, K.R. Smith, J.R. Botkin Communication analysis of BRCA1 genetic counseling

J. Genet. Couns., 14 (5) (2005), pp. 377-386

Ellington et al., 2006 L. Ellington, B.J. Baty, J. McDonald, V. Venne, A. Musters, D. Roter, W. Dudley, R.T. Croyle Exploring genetic counseling communication patterns: the role of teaching and counseling approaches J. Genet. Couns., 15 (3) (2006), pp. 179-189

Ellington et al., 2007 L. Ellington, A. Maxwel, B.J. Baty, D. Roter, W.N. Dudley, A.Y. Kinney Genetic counseling communication with an African American BRCA1 kindred Soc. Sci. Med., 64 (3) (2007), pp. 724-734

Epstein and Street, 2007 R.M. Epstein, R.L. Street Patient-centered Communication in Cancer Care: Promoting Healing and Reducing Suffering 07-6225 National Cancer Institute, Bethesda, MD (2007) NIH Publication

Gattellari et al., 2001 M. Gattellari, P.N. Butow, M.H. Tattersall Sharing decisions in cancer care Soc. Sci. Med., 52 (12) (2001), pp. 1865-1878

Goswami, 2008 U. Goswami Principles of learning, implications for teaching: a cognitive neuroscience perspective J. Philosophy Educ., 42 (3) (2008), pp. 381-399

Hopwood et al., 2003 P. Hopwood, C.J. Van Asperen, G. Borreani, P. Bourret, M. Decruyenaere, S. Dishon, F. Eisinger, D.G. Evans, G. Evers-Kiebooms, L. Gangeri, L. Hagoel, E. Legius, I. Nippert, G. Rennert, B. Schlegelberger, C. Sevilla, H. Sobol, A. Tibben, M. Welkenhuysen, C. Julian-Reynier Cancer genetics service provision: a comparison of seven European centres Commun. Genet., 6 (2003), pp. 192-205 Jansen et al., 2008

J. Jansen, J. Van Weert, N. Van der Meulen, S. Van Dulmen, T. Heeren, J. Bensing Recall in older cancer patients: measuring memory for medical information Gerontologist, 48 (2) (2008), pp. 149-157

Jansen et al., 2010 J. Jansen, J.C. Van Weert, L. Wijngaards-de Meij, S. Van Dulmen, T.J. Heeren, J.M. Bensing The role of companions in aiding older cancer patients to recall medical information Psycho-Oncol., 19 (2) (2010), pp. 170-179

Kasparian et al., 2007 N.A. Kasparian, C.E. Wakefield, B. Meiser Assessment of psychosocial outcomes in genetic counselling research: an overview of available measurement scales J. Genet. Couns., 16 (2007), pp. 693-712

Kelly et al., 2005 K. Kelly, H. Leventhal, M. Andrykowski, D. Toppmeyer, J. Much, J. Dermody, M. Marvin, J. Baran, M. Schwalb Using the common sense model to understand perceived cancer risk in individuals testing for BRCA1/2 mutations Psycho-Oncol., 14 (1) (2005), pp. 34-48 
Albada, A., Ausems, M.G.E.M., Dulmen, S. van. Counselee participation in follow-up breast cancer genetic counselling visits and associations with achievement of the preferred role, cognitive outcomes, risk perception alignment and perceived personal control. Social Science \& Medicine: 2014, 116(sept), 178-186

Langewitz et al., 2002 W. Langewitz, M. Denz, A. Keller, A. Kiss, S. Rüttimann, B. Wössmer Spontaneous talking time at start of consultation in outpatient clinic: cohort study Br. Med. J., 325 (2002), pp. 682-683

Linnenbringer et al., 2010 E. Linnenbringer, J.S. Roberts, S. Hiraki, L.A. Cupples, R.C. Green "I know what you told me, but this is what I think": perceived risk of Alzheimer disease among individuals who accurately recall their genetics-based risk estimate Genet Med, 12 (4) (2010 Apr), pp. 219-227

Lobb et al., 2001 E.A. Lobb, P. Butow, B. Meiser, K. Tucker, A. Barratt How do geneticists and genetic counselors counsel women from high-risk breast cancer families? J. Genet. Couns., 10 (2) (2001), pp. 185-199

Lobb et al., 2002 E.A. Lobb, P.N. Butow, B. Meiser, A. Barratt, C. Gaff, M.A. Young, J. Kirk, G.K. Suthers, K. Tucker Tailoring communication in consultations with women from high risk breast cancer families Br. J. Cancer, 87 (5) (2002), pp. 502-508

Lobb et al., 2004 E.A. Lobb, P.N. Butow, A. Barratt, B. Meiser, C. Gaff, M.A. Young, E. Haan, G. Suthers, M. Gattas, K. Tucker Communication and information-giving in high-risk breast cancer consultations: influence on patient outcomes Br. J. Cancer, 90 (2) (2004), pp. 321-327

Lobb et al., 2005 E.A. Lobb, P. Butow, A. Barratt, B. Meiser, K. Tucker Differences in individual approaches: communication in the familial breast cancer consultation and the effect on patient outcomes J. Genet. Couns., 14 (1) (2005), pp. 43-53

Meiser et al., 2001 B. Meiser, P.N. Butow, A.L. Barratt, V. Schnieden, M. Gattas, J. Kirk, C. Gaff, G. Suthers, K. Tucker Long-term outcomes of genetic counseling in women at increased risk of developing hereditary breast cancer Patient Educ. Couns., 44 (2001), pp. 215-225

Meiser et al., 2008 B. Meiser, J. Irle, E. Lobb, K. Barlow-Stewart Assessment of the content and process of genetic counseling: a critical review of empirical studies J. Genet. Couns., 17 (2008), pp. 434-451

Metcalfe et al., 2007 A. Metcalfe, J. Werrett, L. Burgess, C. Clifford Psychosocial impact of the lack of information given at referral about familial risk for cancer Psycho-Oncol., 16 (5) (2007), pp. 458-465

Michie et al., 2003 S. Michie, J.A. Smith, V. Senior, T.M. Marteau Understanding why negative genetic test results sometimes fail to reassure Am. J. Med. Genet., 119A (2003), pp. 340-347

Noldus et al., 2000 L. Noldus, R. Trienes, A. Hendriksen, H. Jansen, R. Jansen The Observer Video-Pro: new software for the collection, management, and presentation of time-structured data from videotapes and digital media files Behav. Res. Methods. Instrum. Comput., 32 (2000), pp. 197-206

Pieterse et al., 2005a A.H. Pieterse, A.M. Van Dulmen, M.G.E.M. Ausems, F.A. Beemer, J.M. Bensing Communication in cancer genetic counselling: does it reflect counselees' previsit needs and preferences? Br. J. Cancer, 92 (9) (2005), pp. 1671-1678

Pieterse et al., 2005b A.H. Pieterse, M.G.E.M. Ausems, A.M. Van Dulmen, F.A. Beemer, J.M. Bensing Initial cancer genetic counseling consultation: change in counselees' cognitions and anxiety, and association with addressing their needs and preferences Am. J. Med. Genet. Part, 137 (1) (2005), pp. 27-35

Pieterse et al., 2006 A.H. Pieterse, S. Van Dulmen, S. Van Dijk, J.M. Bensing, M.G.E.M. Ausems Risk communication in completed series of breast cancer genetic counseling visits Genet. Med., 8 (11) (2006), pp. 688-696

Pieterse et al., 2007 A.H. Pieterse, A.M. Van Dulmen, F.A. Beemer, J.M. Bensing, M.G.E.M. Ausems Cancer genetic counseling: communication and counselees' post-visit satisfaction, cognitions, anxiety, and needs fulfillment J. Genet. Couns., 16 (1) (2007), pp. 85-96

Pieterse et al., 2011 A. Pieterse, M. Ausems, P. Spreeuwenberg, S. Van Dulmen Longerterm influence of breast cancer genetic counseling on cognitions and distress: smaller benefits for affected versus unaffected women Patient Educ. Couns., 85 (3) (2011), pp. 425-431

Resta et al., 2006 R. Resta, B. Bowles Biesecker, R.L. Bennett, S. Blum, S. Estabrooks Hahn, M.N. Strecker, J.L. Williams A new definition of genetic counseling: National Society of Genetic Counselors' task force report J. Genet. Couns., 15 (2006), pp. 77-83 
Albada, A., Ausems, M.G.E.M., Dulmen, S. van. Counselee participation in follow-up breast cancer genetic counselling visits and associations with achievement of the preferred role, cognitive outcomes, risk perception alignment and perceived personal control. Social Science \& Medicine: 2014, 116(sept), 178-186

Roter and Larson, 2002 D. Roter, S. Larson The Roter Interaction Analysis System (RIAS): utility and flexibility for analysis of medical interactions Patient Educ. Couns., 46 (4) (2002), pp. 243-251

Roter, 2006 D. Roter The Roter Method of Interaction Process Analysis Johns Hopkins School of Public Health (2006) www.riasworks.com

Roter et al., 2007 D.L. Roter, L.H. Erby, S. Larson, L. Ellington Assessing oral literacy demand in genetic counseling dialogue: preliminary test of a conceptual framework Soc. Sci. Med., 65 (7) (2007), pp. 1442-1457

Roter et al., 2008 D.L. Roter, S.M. Larson, M.C. Beach, L.A. Cooper Interactive and evaluative correlates of dialogue sequence: a simulation study applying the RIAS to turn taking structures Patient Educ. Couns., 71 (1) (2008), pp. 26-33

Roter et al., 2009 D.L. Roter, L. Erby, S. Larson, L. Ellington Oral literacy demand of prenatal genetic counseling dialogue: predictors of learning Patient Educ. Couns., 75 (3) (2009), pp. 392-397

Sandvik et al., 2002 M. Sandvik, H. Eide, M. Lind, P.K. Graugaard, J. Torper, A. Finset Analyzing medical dialogues: strength and weakness of Roter's interaction analysis system (RIAS) Patient Educ. Couns., 46 (4) (2002), pp. 235-241

Smerecnik et al., 2009 C.M.R. Smerecnik, I. Mesters, E. Verweij, N.K. De Vries, H. De Vries A systematic review of the impact of genetic counseling on risk perception accuracy J. Genet. Couns., 18 (2009), pp. 217-228

Smets et al., 2006 E.M.A. Smets, A.H. Pieterse, C.M. Aalfs, M.G.E.M. Ausems, A.M. Van Dulmen The perceived personal control (PPC) questionnaire as an outcome of genetic counseling Am. J. Med. Genet., 140A (2006), pp. 843-850

Sousa, 2006 D.A. Sousa How the Brain Learns Thousand Oaks, California (2006) Stiles, 1989

W.B. Stiles Evaluating medical interview process components: null correlations with outcomes may Be misleading Med. Care, 27 (2) (1989), pp. 212-220

Street et al., 2009 R.L. Street Jr., G. Makoul, N.K. Arora, R.M. Epstein How does communication heal? Pathways linking clinician-patient communication to health outcomes Patient Educ. Couns., 74 (3) (2009), pp. 295-301

Sutherland et al., 1989 H.J. Sutherland, H.A. Llewellyn-Thomas, G.A. Lockwood, D.L. Tritchler, J.E. Till Cancer patients: their desire for information and participation in treatment decisions J. R. Soc. Med., 82 (5) (1989), pp. 260-263

Van der Meulen et al., 2008 N. Van der Meulen, J. Jansen, S. Van Dulmen, J. Bensing, J. Van Weert Interventions to improve recall of medical information in cancer patients: a systematic review of the literature Psycho-Oncol., 17 (2008), pp. 857-868

Van Asperen et al., 2004 C.J. Van Asperen, M.A. Jonker, C.E. Jacobi, J.E. Van DiemenHoman, E. Bakker, M.H. Breuning, J.C. Van Houwelingen, G.H. De Bock Risk estimation for healthy women from breast cancer families: new insights and new strategies Cancer. Epidemiol. Biomarkers. Prev., 13 (2004), pp. 87-93

Van Dijk et al., 2004 S. Van Dijk, W. Otten, C. Van Asperen, D. Timmermans, A. Tibben, M.W. Zoeteweij, S. Silberg, M.H. Breuning Feeling at risk; how women interpret their familial breast cancer risk Am. J. Med. Genet. Part A, 131A (2004), pp. 42-49

Van Dijk et al., 2005 S. Van Dijk, W. Otten, D.R. Timmermans, C.J. Van Asperen, H. Meijers-Heijboer, A. Tibben, M.H. Breuning, J. Kievit What's the message? Interpretation of an uninformative BRCA1/2 test result for women at risk of familial breast cancer Genet. Med., 7 (4) (2005), pp. 239-245

Vos et al., 2011 J. Vos, A.M. Stiggelbout, J. Oosterwijk, E. Gomez-Garcia, F. Menko, J.M. Collee, C.J. Van Asperen, A. Tibben A counselee-oriented perspective on risk communication in genetic counseling: explaining the inaccuracy of the counselees' risk perception shortly after BRCA1/2 test result disclosure Genet. Med., 13 (9) (2011), pp. 800-811

Wang et al., 2004 C. Wang, R. Gonzalez, S.D. Merajver Assessment of genetic testing and related counseling services: current research and future directions Soc. Sci. Med., 58 (7) (2004), pp. 1427-1442 
Albada, A., Ausems, M.G.E.M., Dulmen, S. van. Counselee participation in follow-up breast cancer genetic counselling visits and associations with achievement of the preferred role, cognitive outcomes, risk perception alignment and perceived personal control. Social Science 7 \& Medicine: 2014, 116(sept), 178-186

\section{FIGURES AND TABLES}

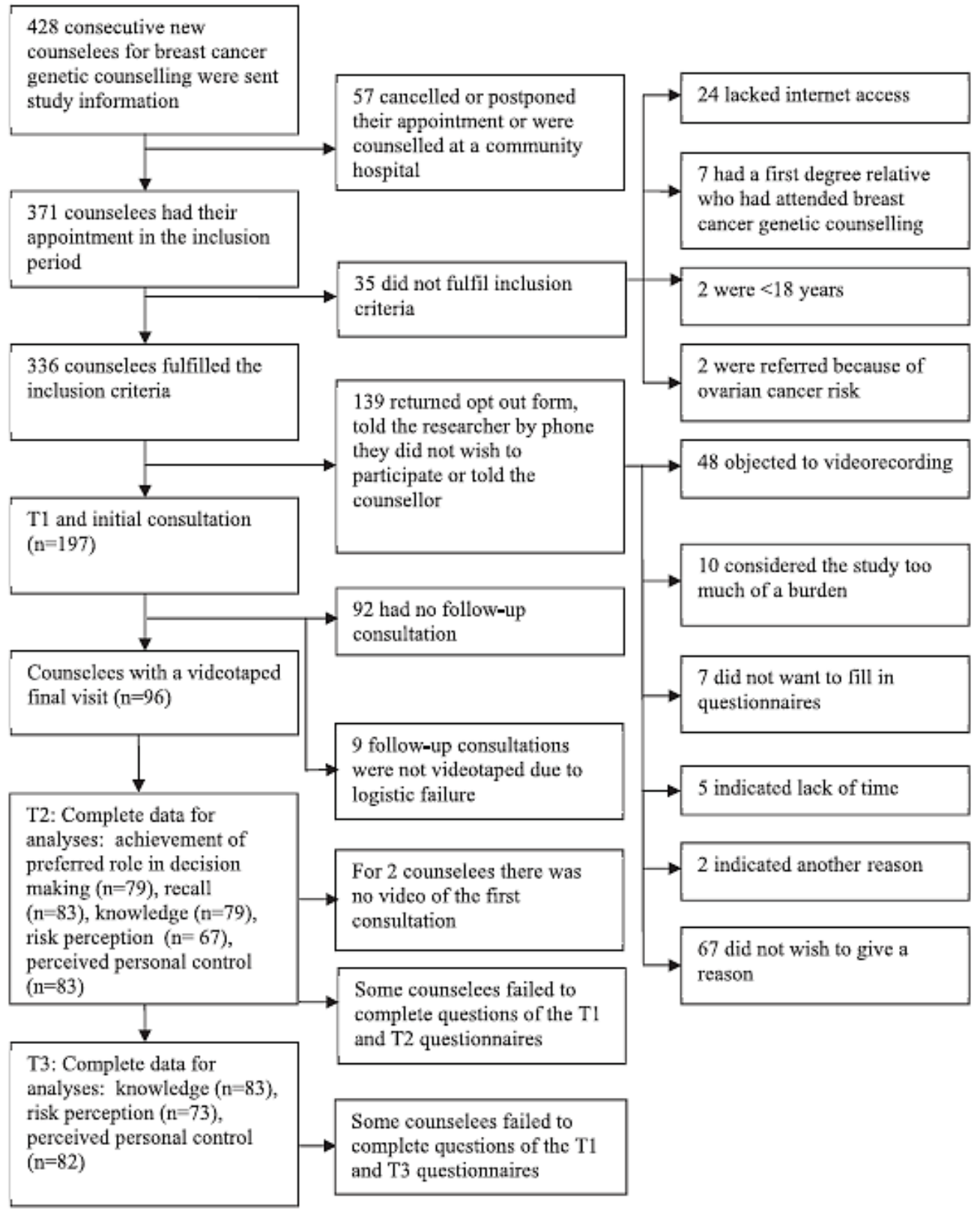

Fig 1. Study procedure.

Table 1. Counselee characteristics $(N=96)$.

\begin{tabular}{|c|c|c|c|c|}
\hline & $n$ & $\%$ & Range & $\begin{array}{c}\text { Mean } \\
\text { (SD) }\end{array}$ \\
\hline Age (years) & - & - & $21-69$ & $44.1(12.2)$ \\
\hline Children (having children) & 73 & 76.0 & - & E \\
\hline
\end{tabular}


Albada, A., Ausems, M.G.E.M., Dulmen, S. van. Counselee participation in follow-up breast cancer genetic counselling visits and associations with achievement of the preferred role, cognitive outcomes, risk perception alignment and perceived personal control. Social Science

\& Medicine: 2014, 116(sept), 178-186

\begin{tabular}{|c|c|c|c|c|}
\hline & $n$ & $\%$ & Range & $\begin{array}{l}\text { Mean } \\
\text { (SD) }\end{array}$ \\
\hline$<$ High school level & 2 & 2.1 & & \\
\hline High school/Secondary education & 26 & 27.7 & & \\
\hline Middle vocational education & 28 & 29.8 & & \\
\hline $\begin{array}{l}\text { University (MSc/BSc)/higher vocational education } \\
\text { (BSc) }\end{array}$ & 38 & 40.4 & & \\
\hline Breast cancer (affected) & 64 & 66.7 & - & - \\
\hline $\begin{array}{l}\text { Indication for DNA-testing for counselee or affected } \\
\text { relative }\end{array}$ & 89 & 92.7 & & \\
\hline DNA-test uptake & 78 & 81.3 & & \\
\hline \multicolumn{5}{|l|}{ BRCA1/2-test result ${ }^{\mathrm{b}}$} \\
\hline Uninformative test result & 65 & 67.7 & - & - \\
\hline BRCA1/2 mutation carrier & 7 & 7.3 & & \\
\hline $50 \%$ risk of being a BRCA1/2 mutation carrier $^{\mathrm{c}}$ & 1 & 1.0 & & \\
\hline Variant of unknown clinical significance (VUCS) & 6 & 6.3 & & \\
\hline \multicolumn{5}{|l|}{ Breast cancer risk category ${ }^{\mathrm{d}}$} \\
\hline Population (<20\% lifetime risk) & 51 & 53.1 & & \\
\hline Moderate (20-30\% lifetime risk) & 29 & 30.2 & & \\
\hline High $(\geq 30 \%$ lifetime risk $)$ & 16 & 16.7 & & \\
\hline
\end{tabular}

\begin{tabular}{||l|l|l|l|l||}
\hline \hline & Pre-counselling (T1) & \multicolumn{2}{|l||}{ Post counselling (T2) } \\
\hline \hline Preferred level of involvement in decision making & & \\
\hline Counselor making decisions (1,2) & 6 & 6.4 & 9 & 11.4 \\
\hline Shared decision making (3) & 43 & 45.7 & 28 & 35.4 \\
\hline \hline Counselee making decisions (4,5) & 45 & 47.9 & 42 & 53.2 \\
\hline Evaluation of involvement in decision making & & \\
\hline Counselor made decisions (1,2) & & & 18 & 22.8 \\
\hline Shared decision making (3) & & & 27 & 34.2 \\
\hline Counselee made decisions (4,5) & & & 34 & 43.0 \\
\hline
\end{tabular}

a. 2 missing values.

b. The total number of test-results counts 79 instead of the 78 counselees with test uptake as one test result indicated a BRCA1/2-mutation as well as a VUCS.

c. Breast cancer unaffected counselees with a first degree relative who tested positive for a BRCA1/2 mutation.

d. The lifetime risk of developing breast cancer (again) for the counselee as estimated by the counsellor at $\mathrm{T} 2$. 
Albada, A., Ausems, M.G.E.M., Dulmen, S. van. Counselee participation in follow-up breast cancer genetic counselling visits and associations with achievement of the preferred role, cognitive outcomes, risk perception alignment and perceived personal control. Social Science \& Medicine: 2014, 116(sept), 178-186

Table 2. Counselees' mean level of information recall, knowledge, perceived personal control, the percentage of counselees who achieved their preferred role in decision making and the percentage of counselees with an accurate risk perception.

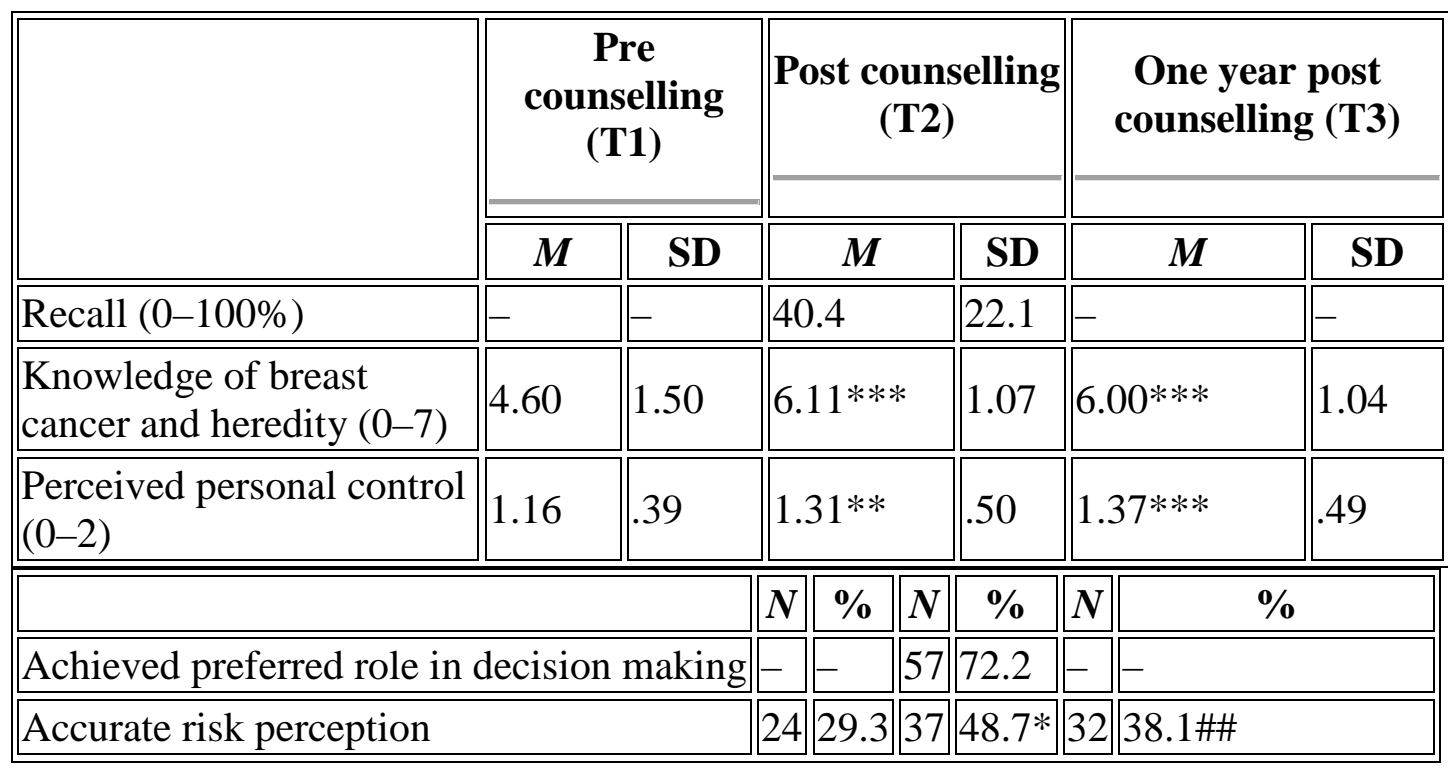

Statistical significances (two-sided $t$-tests and Chi2).

Difference with the pre-counselling value $* P<.05$, ${ }^{* *} P<.01, * * * P<.001$.

Difference between the post-counselling and one-year post counselling value ${ }^{\# \#} P<$ .01 .

Table 3. Visit characteristics of the follow-up consultations compared with the first consultations.

\begin{tabular}{|c|c|c|c|}
\hline & \begin{tabular}{|c|}
$\begin{array}{c}\text { First } \\
\text { consultation (n } \\
=94)\end{array}$ \\
\end{tabular} & $\begin{array}{c}\begin{array}{c}\text { First consultation } \\
\text { without family history } \\
\text { phase }(N=93)\end{array} \\
\end{array}$ & \begin{tabular}{|c|} 
Follow-up \\
consultation $(N=$ \\
$94)$ \\
\end{tabular} \\
\hline & $M(\mathrm{SD})$ & $M(\mathrm{SD})$ & $M(\mathrm{SD})$ \\
\hline $\begin{array}{l}\text { Percentage of } \\
\text { counselee utterances }\end{array}$ & $44.27(5.72)^{* * *}$ & $40.18(7.59)^{* * *}$ & 48.14 (5.97) \\
\hline Interactivity & $5.57(1.52)^{*}$ & $4.45(1.55)^{* * *}$ & $6.05(1.72)$ \\
\hline $\begin{array}{l}\text { Counselee questions } \\
\text { as percentage of all } \\
\text { utterances }\end{array}$ & $1.45(1.05)^{* *}$ & $1.84(1.30)$ & $2.08(1.32)$ \\
\hline Duration (min) & \begin{tabular}{|l}
49.88 \\
$(15.83) * * *$
\end{tabular} & $37.53(14.20)^{* * *}$ & 23.73 (14.47) \\
\hline
\end{tabular}

Statistical significance (two-sided) of the difference with the follow-up consultation ( $t$-tests).

$* P<.05$.

$* * P<.01$.

$* * * P<.001$. 
Albada, A., Ausems, M.G.E.M., Dulmen, S. van. Counselee participation in follow-up breast cancer genetic counselling visits and associations with achievement of the preferred role, cognitive outcomes, risk perception alignment and perceived personal control. Social Science 7

Table 4. Associations of counselee participation in the follow-up breast cancer genetic counselling visit with outcomes; Beta's and standard errors from multilevel regression analyses.

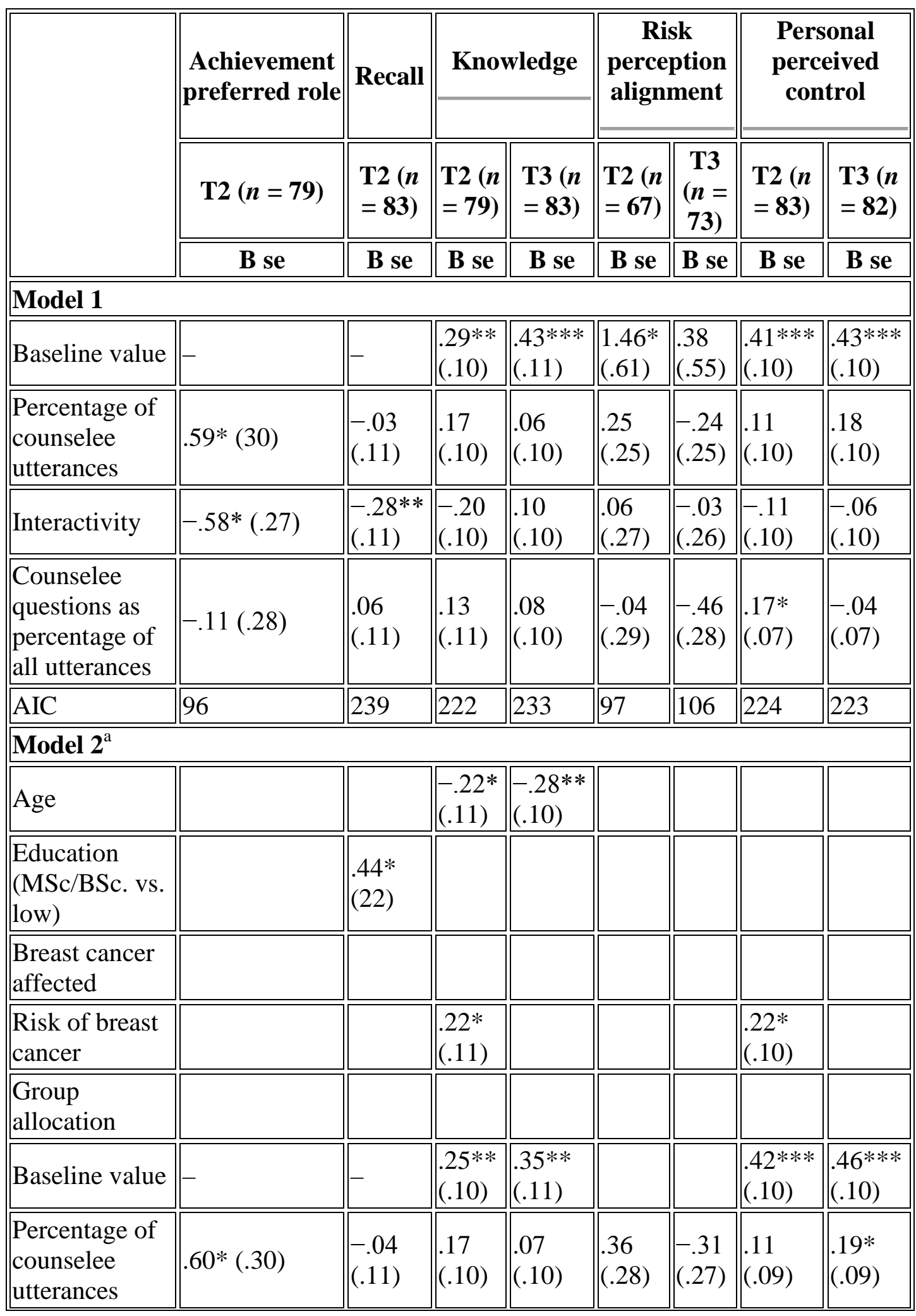


Albada, A., Ausems, M.G.E.M., Dulmen, S. van. Counselee participation in follow-up breast cancer genetic counselling visits and associations with achievement of the preferred role, cognitive outcomes, risk perception alignment and perceived personal control. Social Science 7 \& Medicine: 2014, 116(sept), 178-186

\begin{tabular}{|c|c|c|c|c|c|c|c|c|}
\hline & \multirow{2}{*}{$\begin{array}{c}\begin{array}{c}\text { Achievement } \\
\text { preferred role }\end{array} \\
\text { T2 }(n=79)\end{array}$} & \multirow{2}{*}{$\begin{array}{l}\text { Recall } \\
\text { T2 (n } \\
=83)\end{array}$} & \multicolumn{2}{|c|}{ Knowledge } & \multicolumn{2}{|c|}{$\begin{array}{c}\text { Risk } \\
\text { perception } \\
\text { alignment }\end{array}$} & \multicolumn{2}{|c|}{$\begin{array}{c}\text { Personal } \\
\text { perceived } \\
\text { control }\end{array}$} \\
\hline & & & $\begin{array}{l}\text { T2 (n } \\
=79)\end{array}$ & $\begin{array}{l}\text { T3 }(n \\
=83)\end{array}$ & $\begin{array}{l}\text { T2 }(n \\
=67)\end{array}$ & $\begin{array}{c}\text { T3 } \\
(n= \\
73) \\
\end{array}$ & $\begin{array}{l}\text { T2 (n } \\
=83)\end{array}$ & $\begin{array}{l}\text { T3 (n } \\
=82)\end{array}$ \\
\hline & B se & B se & B se & B se & B se & B se & B se & B se \\
\hline Interactivity & $-.79 *(32)$ & \begin{tabular}{|l}
$-.29 *$ \\
$(.11)$ \\
\end{tabular} & \begin{tabular}{|l|}
-.16 \\
$.111)$ \\
\end{tabular} & \begin{tabular}{|l|}
13 \\
$(.11)$ \\
\end{tabular} & \begin{tabular}{|l|}
.27 \\
$(.30)$ \\
\end{tabular} & \begin{tabular}{|l|}
. .15 \\
$(.28)$ \\
\end{tabular} & \begin{tabular}{|l|}
.- .04 \\
$(.10)$
\end{tabular} & \begin{tabular}{|l|}
-.02 \\
$(.10)$ \\
\end{tabular} \\
\hline \begin{tabular}{|l|} 
Counselee \\
questions as \\
percentage of \\
all utterances
\end{tabular} & $-.01(.31)$ & \begin{tabular}{|l}
.01 \\
$(.12)$
\end{tabular} & $\begin{array}{l}.01 \\
(.11)\end{array}$ & $\begin{array}{l}-.03 \\
(.11)\end{array}$ & $\begin{array}{l}-.13 \\
(.34)\end{array}$ & $\begin{array}{l}-.43 \\
(.33)\end{array}$ & \begin{tabular}{|l}
.13 \\
$(.08)$
\end{tabular} & $\begin{array}{l}-.09 \\
(.10)\end{array}$ \\
\hline AIC & 105 & 244 & 221 & 234 & 100 & 110 & 228 & 225 \\
\hline
\end{tabular}

***P<.001; **P<.01; *P<.05.

a. Only Beta's of control variables reaching statistical significance are shown. 